\title{
Alan Saville (31 December 1946 - 19 June 2016): One of Britain's finest lithics specialists
}

\author{
Torben Bjarke Ballin
}

1. Lithic Research, Stirlingshire, UK. Email: lithicresearch@btinternet.com;

2. Honorary Research Fellow, University of Bradford, UK.

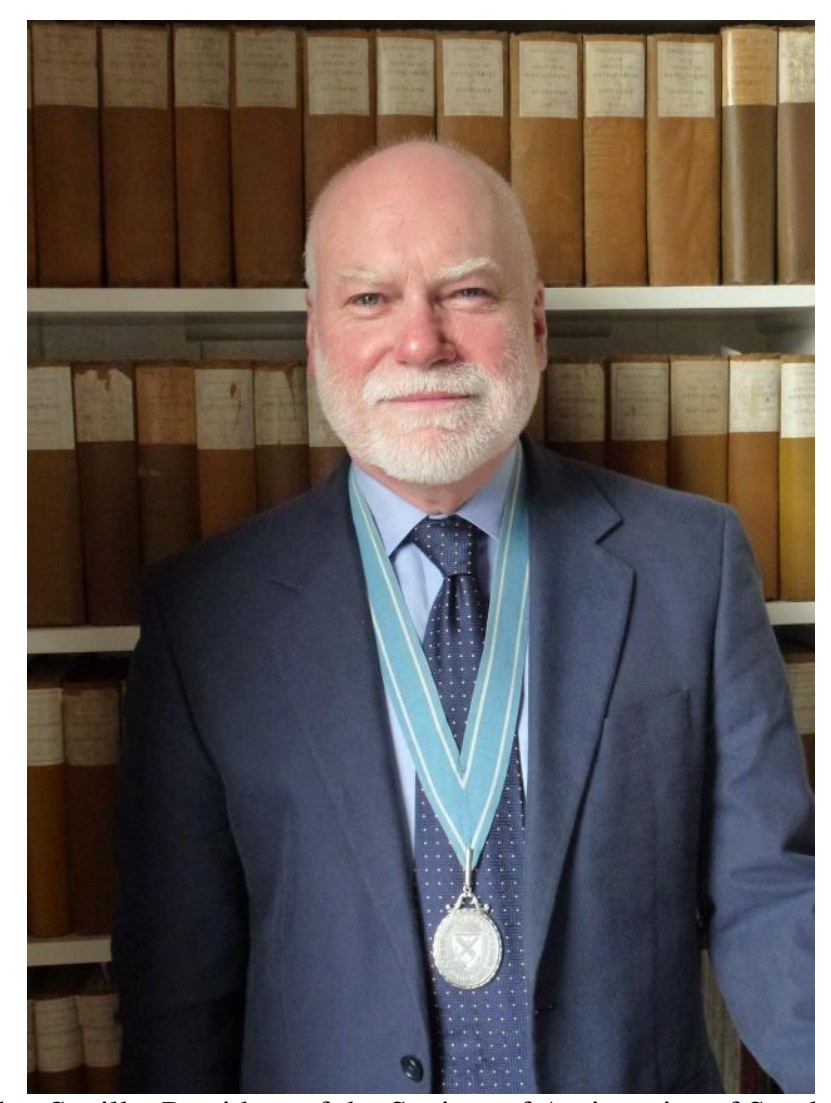

Alan Saville, President of the Society of Antiquaries of Scotland (photo courtesy of Society of Antiquaries of Scotland).

Alan Saville had a long and distinguished career in British archaeology, and following his education and early archaeological background in England, he has latterly been associated mainly with Scottish archaeology, where he held the post of Senior Curator at the Department of Scottish Archaeology and History, National Museums Scotland, Edinburgh. Through his carrier, Saville had many roles and his achievements and posts include, inter alia, being cofounder of the Lithic Studies Society and its newsletter Lithics; the Editor of the European

Published by the School of History, Classics and Archaeology, University of Edinburgh ISSN: 2055-0472. URL: http://journals.ed.ac.uk/lithicstudies/

This work is licensed under a Creative Commons Attribution 2.5 UK: Scotland License. 
Journal of Archaeology (EAA); Chair of the Scottish Treasure Trove Unit; organiser and coorganiser of several important conferences, such as 'Mesolithic Scotland and its Neighbours' in 1999 (Saville 2004b) and 'Flint and Stone in the Neolithic Period' in 2005 (Saville 2011a); co-chair of the Scottish Archaeological Research Framework's (SCARF) Upper PalaeolithicMesolithic panel; and, towards the end, President of the Society of Antiquaries of Scotland.

However, the purpose of this biography is to present Alan Saville's achievements as one of Britain's - and indeed Europe's - finest, most enthusiastic, knowledgeable and productive lithics specialists. Just as the above overview of Saville's long carrier is a brief summary, his production as a lithics specialist is so extensive that the following review of his contribution to the world of lithics is also in summary form.

At the most fundamental level, Saville was influential in defining lithic typology, not least the typology associated with microliths. Where most of the $20^{\text {th }}$ century is characterized by analysts describing microliths in almost painful detail, referring to numerous microlith types and sub-types, he reduced them by asking which details might actually have any relevance to our interpretation of prehistoric sites and life, and suggested the use of only a few basic forms, such as - in the Scottish later Mesolithic - scalene triangles, crescents, edgeblunted pieces and indeterminate fragments $(1980 ; 1981 \mathrm{a} ; 1981 \mathrm{~b}) . \mathrm{He}$ was also instrumental in the definition of a set of general rules for the illustration of lithic artefacts (Martingell \& Saville 1988).

Saville applied his typo-technological insight to the discussion of prehistoric periods and phases, and was a key contributor in the definition of some English Mesolithic phases (e.g. the Honey Hill Phase; Saville 1980; 1981a; 1981b), but he was also able to define an approximate date for the transition between the Scottish Early and Late Mesolithic periods (with the key diagnostic types being isosceles and scalene triangular microliths) at a considerably earlier time than many may have anticipated, c. 8,500 cal BC (Saville 2008). Following the 1999 conference at National Museums Scotland, he produced an excellent overview of the Scottish Mesolithic period for the proceedings which followed (Saville 2004), and with colleagues on the ScARF panel he produced an updated and much more detailed overview in 2012 (Saville \& Wickham-Jones 2012), which is available online.

Over the last decade, Saville worked with the author and other colleagues on the establishment of a Scottish late Upper Palaeolithic period, and on the definition of the involved lithic industries. They include: The Hamburgian (Ballin et al. 2010; forthcoming); the Federmesser Culture (Saville \& Ballin 2009); and the Ahrensburgian (Ballin \& Saville 2003). His publication of the excavation of An Corran on Skye shed light on the Scottish Early Mesolithic period and its lithic artefacts, as well as on the environment of the An Corran site (Saville et al. 2012). His paper on the site at Cramond, Edinburgh, dealt with issues relating to the Scottish Late Mesolithic, as well as general Mesolithic questions (Saville 2008).

He also produced several papers in which he defined British Early Neolithic industries (Saville 2002; 2006a), and he discussed Early Neolithic depositional practices such as those associated with two Scottish caches (Auchenhoan, Kintyre and Portpatrick, Dumfries \& Galloway) of polished axeheads and flakes from Antrim in Northern Ireland (Saville 1999a; 1999b). His work on the Hazelton North long barrow in Gloucestershire informed us on Mesolithic as well as Early Neolithic lithic objects, but also on British long barrows and Early Neolithic burial practices. Among other things, he carried out a refitting analysis of that lithic assemblage to investigate distributional patterns within the Mesolithic and Neolithic elements of the assemblage. The analysis also provided information on flint reduction strategies (Saville 1990).

One of Saville's main interests has been the prehistoric procurement of flint, where he has contributed greatly to the topic of Neolithic flint mining. As part of this work, he planned 
and undertook the excavation in 1971-72 of one of the Grimes Graves mine shafts and its surrounding debris, and the publication of the results shed light on not just the Late Neolithic and Middle Bronze Age mining operations, but also on the associated industries, their artefact typologies and the applied operational schemas (Saville 1981).

In the early 1990s, Saville undertook excavations at two mining complexes at Den of Boddam and Skelmuir Hill in Aberdeenshire, and during his final years he spent a large proportion of his time in the preparation of these two sites and their recovered assemblages of flint debris for publication. Both mining areas date to the later Neolithic period, and his many papers on the two sites have discussed the mining operations themselves, later Neolithic typology and, first and foremost, the applied Levallois-like technique so characteristic of this period (Bridgland et al. 1997; Saville 1995; 2003a; 2003b; 2005a; 2006b; 2008b; 2011b).

Over the years, Saville analysed and published numerous lithic assemblages investigated as part of his work at National Museums Scotland, e.g. Skara Brae (forthcoming) and Kilellan Farm (2005). He also published numerous individual lithic objects discovered in the National Museum's stores or in connection with his work for the Treasure Trove Unit, e.g. Scottish earlier Palaeolithic objects (1997); a likely Scandinavian-style Neolithic tanged point from eastern Scotland (1998); possible Orcadian microliths (1996; 2000); and flint daggers from Northumberland (2012).

Those of us who have worked with Alan Saville will remember our deep, thorough and engaged discussions of lithics in all their shapes and sizes, and not least the help and advice we received if and when we needed it. If you asked Saville to comment on a manuscript, he would not simply skim the text and give you a few general comments - he would invest hours of his time, and the manuscript would be returned more red than black. However, following his intervention, the paper would always be a better one than it was originally.

After a protracted battle with cancer, Alan Saville sadly passed away Sunday 19 June 2016. I am personally grateful to Alan Saville for all the help and support I have received over the years, and he will be thoroughly missed. His death is a notable loss to Scottish and British lithic research.

\section{Bibliography}

Ballin, T.B. \& Saville, A. 2003, An Ahrensburgian-type tanged point from Shieldaig, Wester Ross, Scotland, and its implications. Oxford Journal of Archaeology, 22(2): 115-131. doi:10.1111/1468-0092.t01-1-00001

Ballin, T.B., Saville, A., Tipping, R., \& Ward, T. 2010, An Upper Palaeolithic Flint and Chert Assemblage from Howburn Farm, South Lanarkshire, Scotland: First Results. Oxford Journal of Archaeology, 29(4): 323-360. doi:10.1111/j.1468-0092.2010.00352.x

Ballin, T.B., Saville, A., Tipping, R., \& Ward, T. (2016), Additional Late Hamburgian Lithic Artefacts from Howburn in South Lanarkshire, Scotland. (Manuscript in preparation for Proceedings of the Prehistoric Society, unsubmitted). $76 \mathrm{p}$.

Bridgland, D.R., Saville, A. \& Sinclair, J.M. 1997, New evidence for the origin of the Buchan Ridge Gravel, Aberdeenshire. Scottish Journal of Geology, 33: 43-50. doi:10.1144/sjg33010043

Martingell, H., \& Saville, A. 1988, The Illustration of Lithic Artefacts: A Guide to Drawing Stone Tools for Specialist Reports. Lithic Studies Society Occasional Papers Vol. 3 \& AAI\&S Technical Papers Vol. 9. Lithic Studies Society \& Association of Archaeological Illustrators \& Surveyors, Northampton, 30 p. 
Saville, A. 1980, Five flint assemblages from excavated sites in Wiltshire. Wiltshire Archaeological Magazine, 72-73: 1-27.

Saville, A. 1981a, Grimes Graves, Norfolk. Excavations 1971/72: Volume II. The Flint Assemblage. Department of the Environment Archaeological Reports Vol. 11. Her Majesty's Stationery Office, London, $181 \mathrm{p}$.

Saville, A. 1981b, Honey Hill, Elkington: a Northamptonshire Mesolithic site. Northamptonshire Archaeology 16: 1-13.

Saville, A. 1981c, Mesolithic Industries in Central England: an exploratory investigation using microlith typology. The Archaeological Journal, 138: 49-71. doi:10.1080/00665983.1981.11078661

Saville, A. 1990, Hazleton North, Gloucestershire, 1979-82: The excavation of a Neolithic long cairn of the Cotswold-Severn group. English Heritage Archaeological Report Vol. 13. Historic Buildings \& Monuments Commission for England, London, $281 \mathrm{p}$.

Saville, A. 1995, GB 20 Den of Boddam near Peterhead, Grampian Region, Scotland. GB 21 Skelmuir Hill, Grampian Region, Scotland. Prehistoric exploitation of flint from the Buchan Ridge Gravels, Grampian region, north-east Scotland. Archaeologia Polona, 33: 353-368.

Saville, A. 1996, Lacaille, Microliths and the Mesolithic of Orkney. In: The Early Prehistory of Scotland, (Pollard, T., \& Morrison, A., Eds.), Edinburgh University Press, Edinburgh: p. 213-224.

Saville, A. 1997, Palaeolithic handaxes in Scotland. Proceedings of the Prehistoric Society of Scotland, 127: 1-16.

Saville A. 1998, Tain (Tain parish); flint projectile point. Discovery \& Excavation in Scotland, 1998: 62-63.

Saville, A. 1999a, A Cache of Flint Axeheads and Other Flint Artefacts from Auchenhoan, near Campbelltown, Kintyre, Scotland. Proceedings of the Prehistoric Society, 65: 83-114. doi:10.1017/S0079497X0000195X

Saville, A. 1999b, The Portpatrick Flint Caches. Proceedings of the Prehistoric Society, 65: 117-123.

Saville, A. 2000, Orkney and Scotland before the Neolithic period. In: Neolithic Orkney in its European Context, Ritchie, A., Ed.), McDonald Institute Monograph. Cambridge University Press, Cambridge: p. 91-100.

Saville, A. 2002, Lithic Artefacts from Neolithic Causewayed Enclosures: Character and Meaning. In: Enclosures in Neolithic Europe. Essays on Causewayed and NonCausewayed Sites, (Varndell, G. \& Topping, P., Eds.), Oxbow Books, Oxford: p. 91-105.

Saville, A. 2003a, Indications of regionalisation in Mesolithic Scotland. In: Mesolithic on the Move. Papers presented at the Sixth International Conference on the Mesolithic in Europe, Stockholm 2000, (Larsson, L., Kindgren, H., Knutsson, K., Loeffler, D. \& Åkerlund, A., Eds.), Oxbow Books, Oxford: p. 230-238.

Saville, A. 2003b, Lithic Resource Exploitation for Artefacts in Prehistoric and Early Historic Scotland. In: Man and Mining - Mensch und Bergbau. Studies in honour of Gerd Weisgerber on occasion of his 65th birthday, (Stöllner, T., Körlin, G., Steffens, G. \& Cierny, J., Eds.), Deutsches Bergbau Museum, Bochum: p. 405-413. 
Saville, A. 2004a, The Material Culture of Mesolithic Scotland. In: Mesolithic Scotland and its Neighbours. The Early Holocene Prehistory of Scotland, its British and Irish Context, and some Northern European Perspectives, (Saville, A. Ed.), Society of Antiquaries of Scotland, Edinburgh: p. 185-220.

Saville, A. (ed.) 2004b, Mesolithic Scotland and its Neighbours. The Early Holocene Prehistory of Scotland, its British and Irish Context, and some Northern European Perspectives, Society of Antiquaries of Scotland, Edinburgh, 458 p.

Saville, A. 2005a, Prehistoric Quarrying of a Secondary Flint Source: Evidence from NorthEast Scotland. In: The Cultural Landscape of Prehistoric Mines, (Topping, P. \& Lynott, M., Eds.), Oxbow Books, Oxford: p. 1-13.

Saville, A. 2005b, Struck lithic artefacts. In Kilellan Farm, Ardnave, Islay. Excavation of a Prehistoric to Early Medieval Site by Colin Burgess and others 1954-76, (Ritchie, A., Ed.), Society of Antiquaries of Scotland, Edinburgh: p. 97-132.

Saville, A. 2006a, The Early Neolithic Lithic Assemblage in Britain: some Chronological Considerations. In: Contribution of Lithics to Early and Middle Neolithic Chronology in France and Neighbouring Regions, (Allard, P., Bostyn, F. \& Zimmermann, A., Eds.), British Archaeological Reports International Series Vol. 1494, Archaeopress, Oxford: p. $1-14$.

Saville, A. 2006b, Flint technology associated with extraction sites in north-east Scotland. In: Stone Age - Mining Age. Proceedings of the VIII International Flint Symposium, Bochum, 1999, (Weisgerber, G., Ed.), Deutsches Bergbau-Museum Bochum, Bochum: p. $449-454$.

Saville, A. 2008a, The Beginning of the Later Mesolithic in Scotland. In: Man - Millennia Environment. Studies in Honour of Romuald Schild, (Sulgostowska, Z. \& Tomaszewski, A.J., Eds.), Institute of Archaeology and Ethnology, Polish Academy of Sciences, Warsaw: p. 207-213.

Saville, A. 2008b, Flint extraction and processing from secondary flint deposits in the northeast of Scotland in the Neolithic period. In: Flint Mining in Prehistoric Europe. Interpreting the archaeological records. European Association of Archaeologists, 12th Annual Meeting, Cracow, Poland, 19th-24th September 2006, (Allard, P., Bostyn, F., Giligny, F. \& Lech, J., Eds.), BAR International Series Vol. 1891, Archaeopress, Oxford: p. 1-10.

Saville, A. (Ed.) 2011a, Flint and Stone in the Neolithic Period. Neolithic Studies Group Seminar Papers Vol. 11, Oxbow Books, Oxford, 315 p.

Saville, A. 2011b, Residues at the Neolithic flint extraction site at Den of Boddam, Aberdeenshire, Scotland. In: Proceedings of the 2nd International Conference of the UISPP Commission on Flint Mining in Pre-and Protohistoric Times (Madrid, 14-17 October 2009), (Capote, M., Consuegra, S., Diaz-del-Rio, P. \& Terradas, X. Eds.), BAR International Series Vol. 2260, Archaeopress, Oxford: p. 19-28.

Saville, A. 2012, Three Early Bronze Age flint daggers from north Northumberland and their typological context. Archaeologia Aeliana, 41: 1-17.

Saville, A. (2016), Skara Brae 1972-73: Struck Lithic Artefacts. (Manuscript in preparation for Skara Brae, Clarke, D. L., Ed., unsubmitted). 25 p. 
Saville, A., \& Ballin, T.B. 2009, Upper Palaeolithic evidence from Kilmelfort Cave, Argyll: A re-evaluation of the lithic assemblage. Proceedings of the Society of Antiquaries of Scotland, 139: 9-45.

Saville, A., \& Wickham-Jones, C. (Eds.) 2012, Palaeolithic and Mesolithic Scotland: ScARF Panel Report. Scottish Archaeological Research Framework, 163 p. Accessed: 30 June 2016.

URL: http://www.scottishheritagehub.com/sites/default/files/u12/ScARF\%20palaeomes \%20June\%202012.pdf

Saville, A., Hardy, K., Miket, R., \& Ballin, T.B. 2012, An Corran, Staffin, Skye: A Rockshelter with Mesolithic and Later Occupation. Scottish Archaeological Internet Reports (SAIR), Vol. 51. Society of Antiquaries of Scotland, Edinburgh, 108 p. Accessed: 30 June 2016.

URL: http://archaeologydataservice.ac.uk/archiveDS/archiveDownload?t=arch-3101/dissemination/pdf/sair51.pdf 